\title{
Stratigraphic Cross Sections of the Niobrara Interval of the Cody Shale and Associated Rocks in the Wind River Basin, Central Wyoming
}

Pamphlet to accompany

Scientific Investigations Map 3370 



\section{Stratigraphic Cross Sections of the Niobrara Interval of the Cody Shale and Associated Rocks in the Wind River Basin, Central Wyoming}

By Thomas M. Finn

Pamphlet to accompany

Scientific Investigations Map 3370 


\section{U.S. Department of the Interior SALLY JEWELL, Secretary}

\section{U.S. Geological Survey Suzette M. Kimball, Director}

\section{U.S. Geological Survey, Reston, Virginia: 2017}

For more information on the USGS - the Federal source for science about the Earth, its natural and living resources, natural hazards, and the environment—visit http://www.usgs.gov or call 1-888-ASK-USGS.

For an overview of USGS information products, including maps, imagery, and publications, visit http://store.usgs.gov/

Any use of trade, firm, or product names is for descriptive purposes only and does not imply endorsement by the U.S. Government.

Although this information product, for the most part, is in the public domain, it also may contain copyrighted materials as noted in the text. Permission to reproduce copyrighted items must be secured from the copyright owner.

Suggested citation:

Finn, T.M., 2017, Stratigraphic cross sections of the Niobrara interval of the Cody Shale and associated rocks in the Wind River Basin, central Wyoming: U.S. Geological Survey Scientific Investigations Map 3370, 19 p., 1 sheet, https://doi.org/10.3133/sim3370.

ISSN 2329-132X (online) 


\section{Contents}

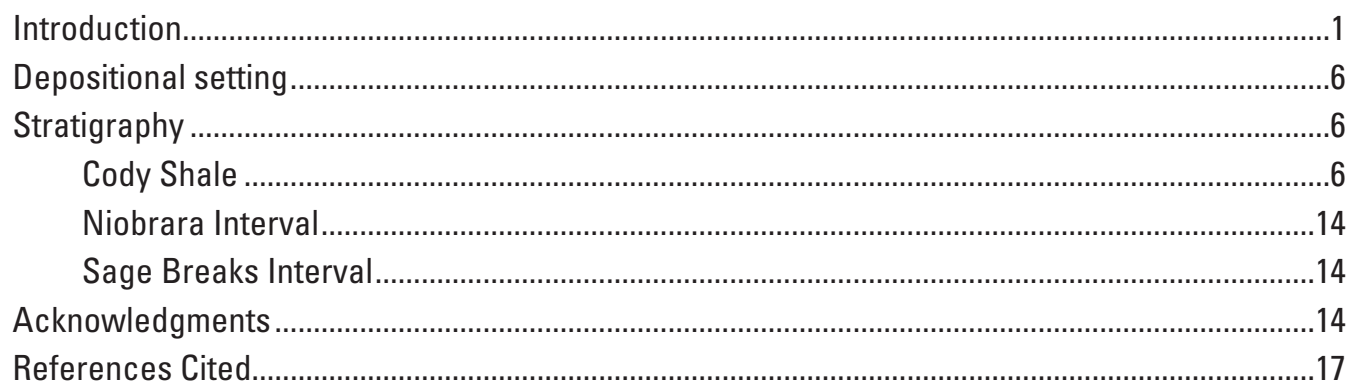

\section{Sheet}

1. Detailed cross sections of Niobrara equivalent strata in the Wind River Basin, Wyoming.

\section{Figures}

1. Map of Rocky Mountain region extending from southern Montana to northern New Mexico showing locations of Laramide sedimentary and structural basins (in brown) and intervening uplifts.

2. Index map of the Wind River Basin Province in central Wyoming showing major structural and physiographic features discussed in the text.

3. Index map of the Wind River Basin showing the cross section lines presented on map sheet.

4. Type log of Lower and lowermost Upper Cretaceous rocks in the southeastern part of the Wind River Basin.

5. Map showing approximate extent of the Western Interior Seaway in North America during late Coniacian (Scaphites depressus Zone).

6. Regional east-west stratigraphic cross section of Cretaceous rocks in the Wind River Basin

7. Paleogeographic reconstruction of the Rocky Mountain region during late Coniacian (Scaphites depressus Zone) time showing major depositional trends. Wind River Basin Province outlined in red....

8. Correlation chart showing stratigraphic relations of mid-Cretaceous rocks in the Wind River Basin and correlation with equivalent rocks at various localities in the Powder River Basin and Denver Basin.

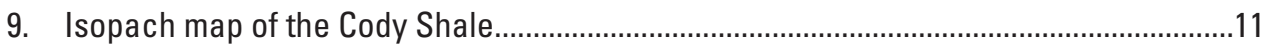

10. Isopach map of the lower shaly member of the Cody Shale...........................................12

11. Isopach map of the upper sandy member of the Cody Shale ..........................................13

12. Isopach map of the Niobrara equivalent interval in the lower part of the Cody Shale. . .15

13. Isopach map of the Sage Breaks equivalent interval in the lower part of the Cody Shale 


\section{Conversion Factors}

\begin{tabular}{|c|c|c|}
\hline Multiply & By & To obtain \\
\hline \multicolumn{3}{|c|}{ Length } \\
\hline inch (in.) & 25.4 & millimeter (mm) \\
\hline foot (ft) & 0.3048 & meter $(\mathrm{m})$ \\
\hline mile (mi) & 1.609 & kilometer $(\mathrm{km})$ \\
\hline \multicolumn{3}{|c|}{ Area } \\
\hline square mile $\left(\mathrm{mi}^{2}\right)$ & 2.590 & square kilometer $\left(\mathrm{km}^{2}\right)$ \\
\hline
\end{tabular}

\section{Datum}

Horizontal coordinate information is referenced to the North American Datum of 1983 (NAD 83).

Altitude, as used in this report, refers to distance above sea level. 


\title{
Stratigraphic Cross Sections of the Niobrara Interval of the Cody Shale and Associated Rocks in the Wind River Basin, Central Wyoming
}

\author{
By Thomas M. Finn
}

\section{Introduction}

The Wind River Basin is one of many structural and sedimentary basins that formed in the Rocky Mountain foreland during the Laramide orogeny. The basin is nearly 200 miles (mi) long, $70 \mathrm{mi}$ wide, and encompasses about 7,400 square miles $\left(\mathrm{mi}^{2}\right)$ in central Wyoming (fig. 1). The basin is bounded by the Washakie Range, Owl Creek uplift, and southern Bighorn Mountains on the north, the Casper arch on the east, the Granite Mountains on the south, and Wind River Range on the west (fig. 2).

The first commercial oil well completed in Wyoming was drilled near an oil seep in 1884 at Dallas dome near the southwestern edge of the Wind River Basin (Biggs and Espach, 1960). Since then many important conventional oil and gas fields producing from reservoirs ranging in age from Mississippian through Tertiary have been discovered in that basin (Keefer, 1969; Fox and Dolton, 1989, 1996; De Bruin, 1993). In addition, an extensive unconventional overpressured basin-centered gas accumulation has been identified in Cretaceous and Tertiary strata in the deeper parts of the basin (Spencer, 1987; Johnson and others, 1996; Jiao and Surdam, 1997; Surdam and others, 1997; Johnson and others, 2007). It has long been suggested that various Upper Cretaceous marine shales, including the Cody Shale, are the principal hydrocarbon source rocks for many of these accumulations (see, for example: Keefer, 1969; Meissner and others, 1984; Fox and Dolton, 1989, 1996; Johnson and Rice, 1993; Nuccio and others, 1996; Schelling and Wavrek, 1999, 2001; and Finn, 2007a). With recent advances and success in horizontal drilling and multistage fracture stimulation, there has been an increase in exploration and completion of wells in these marine shales in other Rocky Mountain Laramide basins that were traditionally thought of only as hydrocarbon source rocks (Colorado Geological Survey, 2011; Sonnenberg, 2011; Williams and Lyle, 2011).

The stratigraphic cross sections presented in this report were constructed as part of a project carried out by the U.S. Geological Survey (USGS) to characterize and evaluate the undiscovered continuous (unconventional) oil and gas resources of the Niobrara interval of the Upper Cretaceous
Cody Shale in the Wind River Basin in central Wyoming. The primary purpose of the cross sections is to show the stratigraphic relationship of the Niobrara equivalent strata and associated rocks in the lower part of the Cody Shale in the Wind River Basin.

Two cross sections were constructed using borehole geophysical logs from 37 wells drilled for oil and gas exploration and production, and one surface section measured by Keefer and Troyer (1964) along East Sheep Creek near Shotgun Butte in the northwestern part of the basin (figs. 2, 3, and map sheet). Both lines originate at the East Sheep Creek surface section and end near Clarkson Hill in the extreme southeastern part of the basin. The northern line extends from the Shotgun Butte area east along the northern margin of the basin to the Madden anticline, then southeast to Tepee Flats and Hells Half Acre, then along the southwest margin of the Casper arch to Clarkson Hill (figs. 2, 3, and map sheet). The southern line extends from the Shotgun Butte area south then east to Alkali Butte and along the southern margin of the basin to the Coalbank Hills, then southeast along the northeast flank of the Rattlesnake Hills to Clarkson Hill (figs. 2, 3, and map sheet). The stratigraphic interval extends from the upper part of the Frontier Formation to the middle part of the Cody Shale. The datum is the base of the "chalk kick" marker bed, a distinctive resistivity peak or zone in the lower part of the Cody Shale. This datum was selected because it is easily identified on most well logs and is present throughout the basin (fig. 4, map sheet).

A gamma ray and (or) spontaneous potential (SP) log was used in combination with a resistivity log to identify and correlate units. Gamma ray and SP logs are typically used to differentiate between sandstone and shale; however, in the Wind River Basin the spontaneous potential response is subdued in some sandstone intervals showing little curve deflection. In areas of greater drilling density, logs from wells located between control wells on the cross sections were used to aid in making correlations. Marine molluscan index fossils collected from nearby outcrop sections were projected into the subsurface to help determine the relative ages of the strata and aid in correlation. The sources for the fossil data are from Cobban (1951, 1969), Yenne and Pipiringos (1954), Keefer and Troyer (1964), Keefer (1972), Landman and Cobban (2007), 


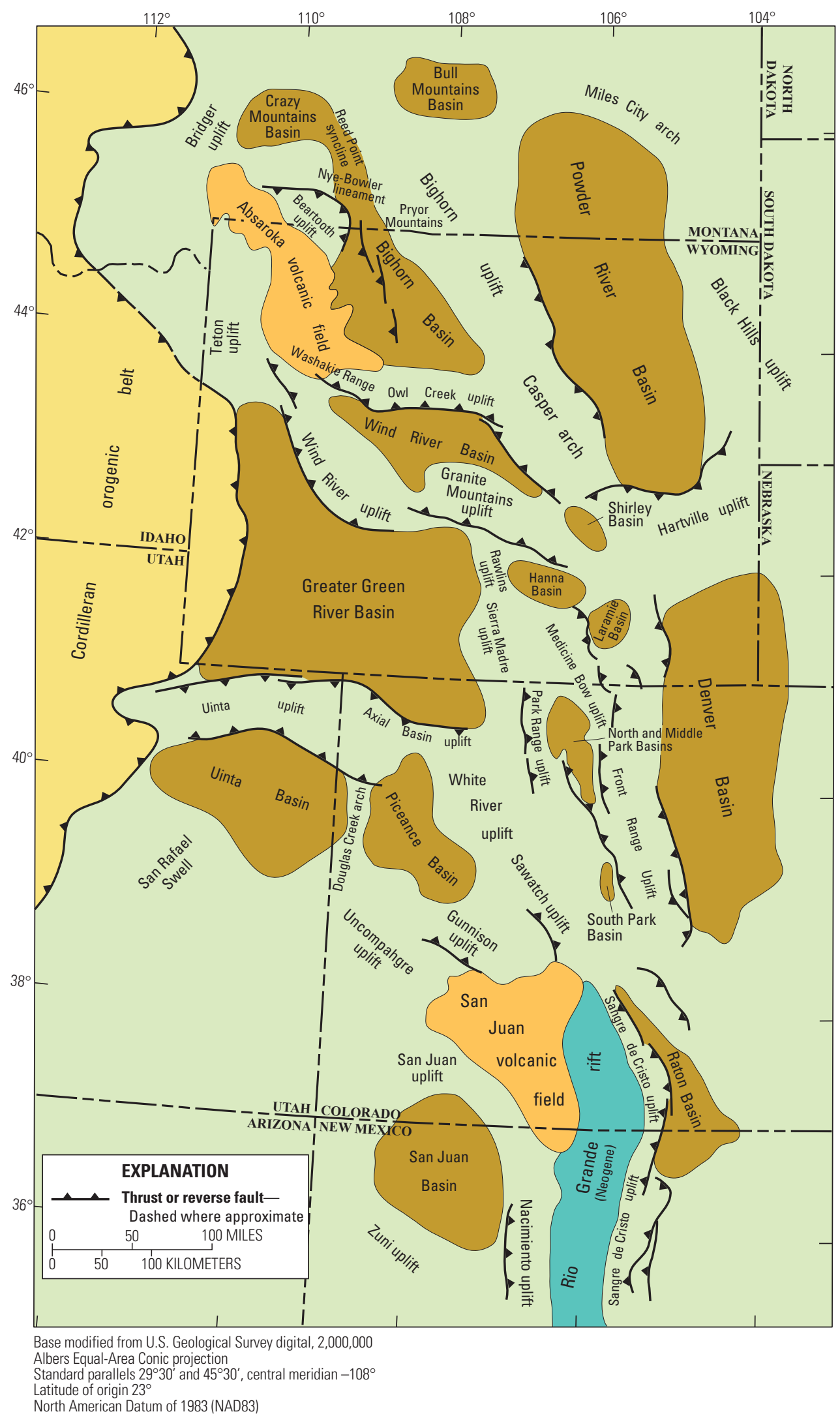

Figure 1. Map of Rocky Mountain region extending from southern Montana to northern New Mexico showing locations of Laramide sedimentary and structural basins (in brown) and intervening uplifts. Modified from Dickinson and others (1988). 


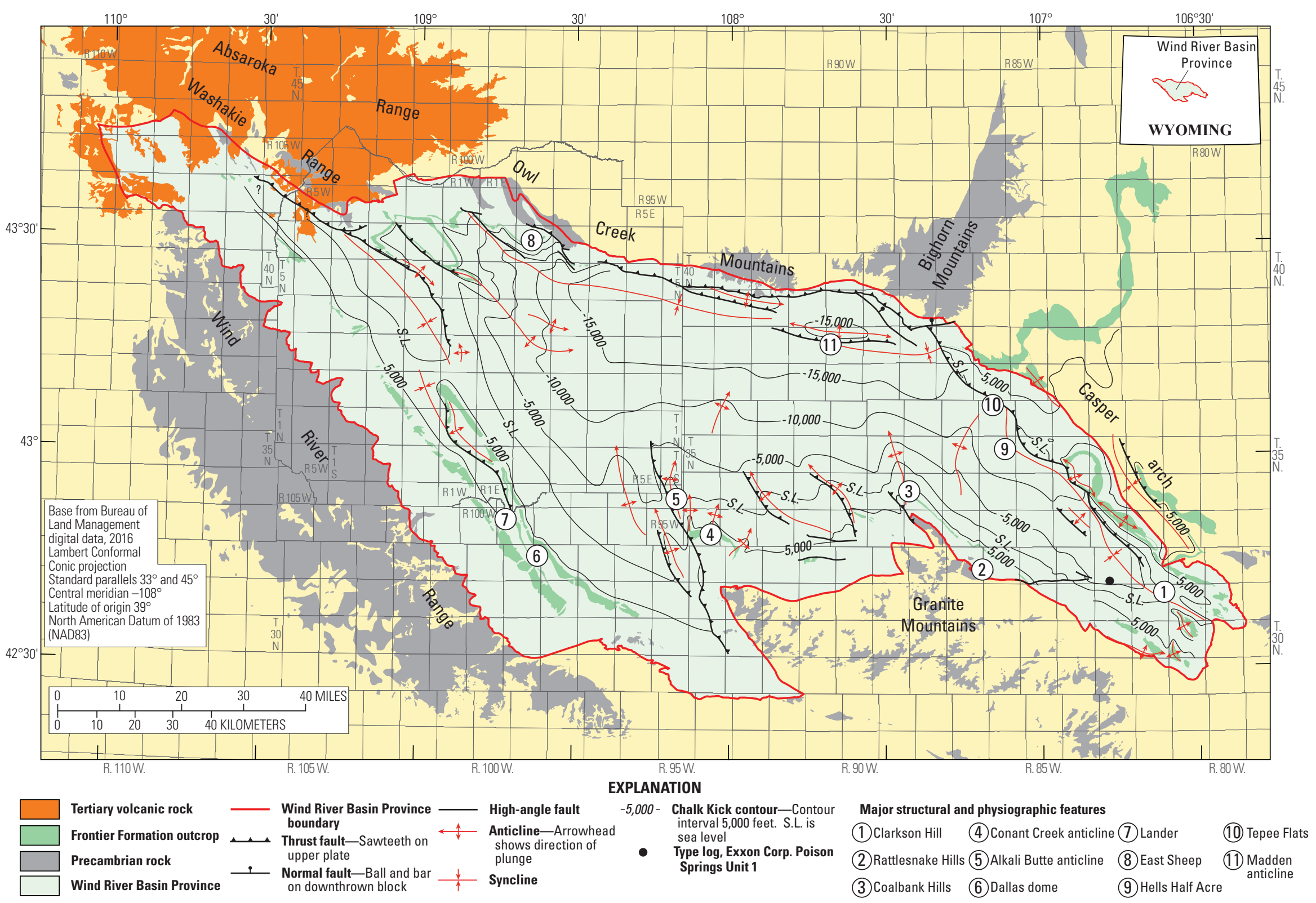

Figure 2. Index map of the Wind River Basin Province in central Wyoming showing major structural and physiographic features discussed in the text: (1) Clarkson Hill, (2) Rattlesnake Hills, (3) Coalbank Hills, (4) Conant Creek anticline, (5) Alkali Butte anticline, (6) Dallas dome, (7) Lander, (8) East Sheep Creek/Shotgun Butte, (9) Hells Half Acre, (10) Teepee Flats gas field, and (11) Madden anticline. Structure contours are drawn at base of the "chalk kick" marker bed. Contour interval is 5,000 feet. S.L., sea level. 


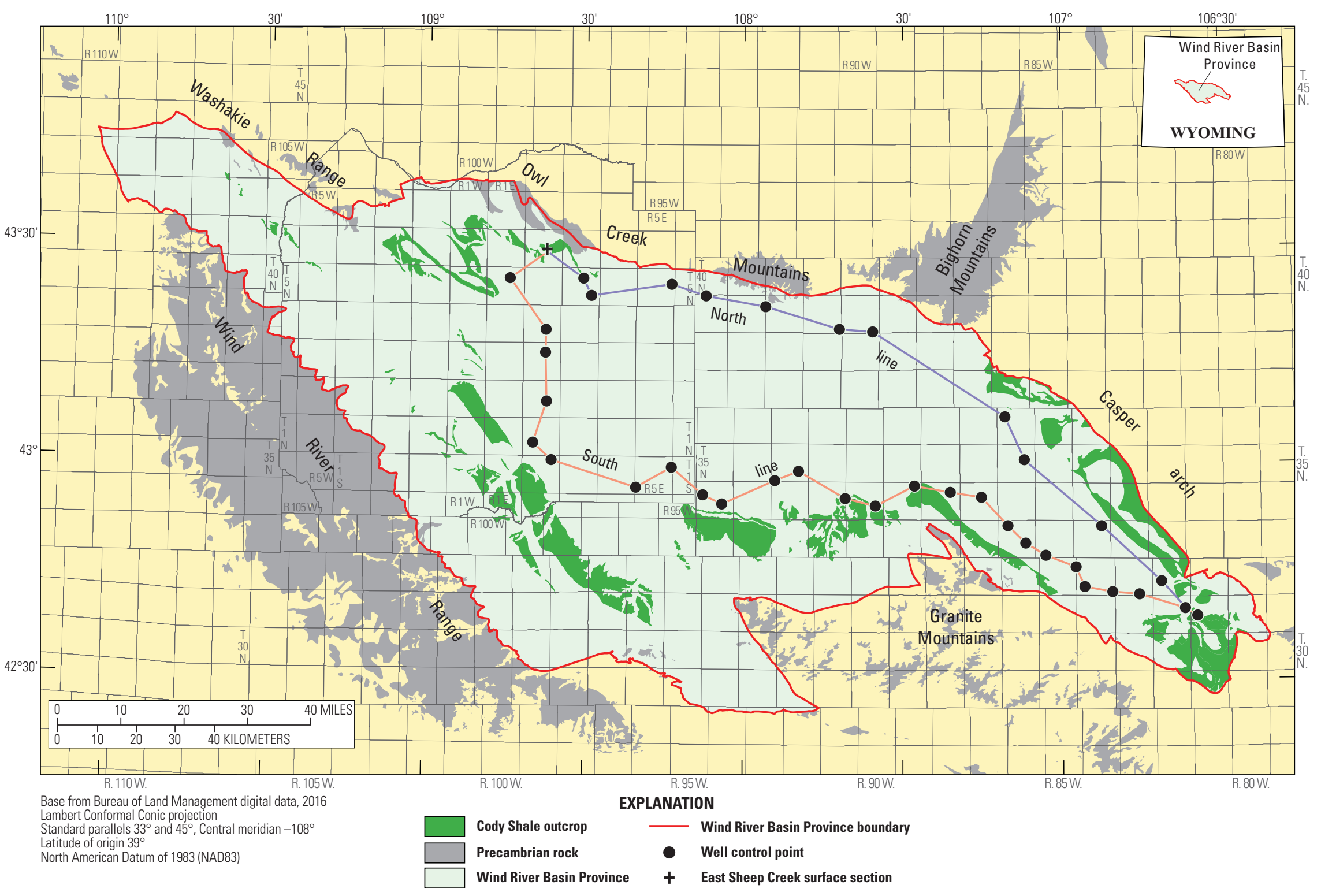

Figure 3. Index map of the Wind River Basin showing the cross section lines presented on map sheet. 


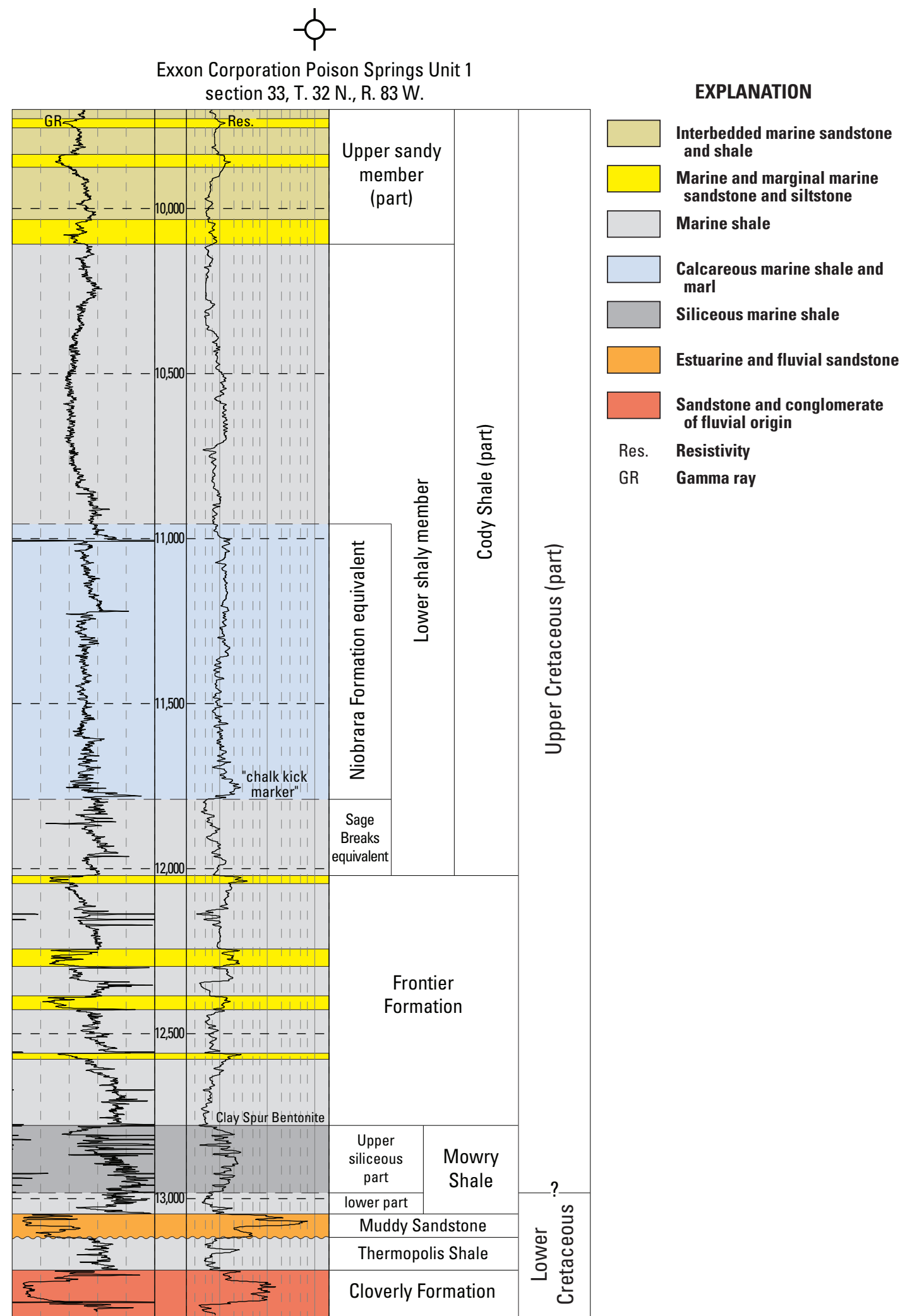

Figure 4. Type log of Lower and lowermost Upper Cretaceous rocks in the southeastern part of the Wind River Basin. GR, gamma ray log; Res., resistivity log. Location shown in figure 2. 
Stratigraphic Cross Sections of the Niobrara Interval of the Cody Shale and Associated Rocks, Wind River Basin, WY

Merewether and Cobban (2007), and from files at the USGS fossil collection in Denver, Colorado (K.C. McKinney, USGS, written commun., 2015). For both sections the horizontal scale is about $1 \mathrm{in}=5.75 \mathrm{mi}$ and the vertical scale is about $1 \mathrm{in}=500$ $\mathrm{ft}$ (map sheet).

\section{Depositional setting}

During much of Late Cretaceous time, the part of Wyoming that is now the Wind River Basin was located near the west edge of the Rocky Mountain foreland basin, an elongate north-south structural depression that developed to the east of the tectonically active Western Cordilleran highlands prior to the Laramide orogeny (figs. 1 and 5). Throughout much of its history, the foreland basin was flooded by a broad epicontinental sea, referred to as the Western Interior Seaway (WIS) that developed in response to foreland basin subsidence and eustatic sea-level rise (Steidtmann, 1993). At its maximum extent, the WIS extended for more than 3,000 mi from the Arctic Ocean to the Gulf of Mexico (fig. 5) (Kauffman, 1977). Erosion of the Western Cordilleran highlands supplied sediment to the basin by eastward-flowing streams; whereas, the eastern shore of the WIS was part of the stable craton that was topographically low and supplied little sediment (Molenaar and Rice, 1988). During much of Late Cretaceous time, sediments accumulated in or adjacent to the WIS as the western shoreline repeatedly advanced and retreated across the western part of the basin resulting in a complex pattern of intertonguing marine and nonmarine deposits (fig. 6). Marginal marine and nonmarine deposits are represented by eastward-thinning wedges of marginal marine and nonmarine sandstone, siltstone, shale, carbonaceous shale, and coal. The marine deposits are represented by westwardthinning tongues of marine shale, siltstone, and marine sandstone (fig. 6). The marine sediments were deposited during widespread marine transgressions creating highstand conditions as the seaway deepened, limiting clastic input, and at times forming anoxic bottom conditions favorable for the preservation of organic matter (Gries and others, 1992). In addition, these transgressions produced two widespread episodes of carbonate deposition in the WIS: the first resulted in the deposition of the Upper Cretaceous Greenhorn Formation, and the second resulted in the deposition of the Upper Cretaceous Niobrara Formation (Longman and others, 1998; Sonnenberg, 2011). The Niobrara interval is characterized by deposition of chalks and marls composed of foraminifers and coccolith debris that accumulated in the sediment-starved eastern part of the seaway (Longman and others, 1998; Sonnenberg, 2011). The chalks grade westward into more siliciclastic beds that were derived from the eroding highlands to the west, diluting the carbonate sediments (Longman and others, 1998; Sonnenberg, 2011) (fig. 7). In the Wind River Basin, the Niobrara equivalent rocks are represented by shales, calcareous shales, marls, siltstones, and sandstones in the lower shaly member of the Cody Shale (fig. 6).

\section{Stratigraphy}

Figure 8 is a correlation diagram showing the stratigraphic nomenclature for the Cody Shale and associated rocks in the Wind River Basin and correlative units at various localities in the Powder River Basin and Denver Basin to the east and southeast, respectively. The Wind River Basin nomenclature is modified from Keefer (1972), and Finn (2007b), the western Powder River Basin nomenclature is modified from Merewether (1996), the northwest Black Hills and Pueblo, Colo. (Denver Basin) nomenclature is modified from Merewether and others (2011). The stratigraphic relationships and nomenclature for the Wind River Basin are also illustrated on the regional stratigraphic cross section in figure 6.

\section{Cody Shale}

The Cody Shale consists of shales, calcareous shales, marls, bentonites, siltstones, and sandstones, with the amount of sandstone and siltstone increasing in the upper part (Keefer, 1972). The main body of the Cody Shale was deposited during a second-order transgressive-regressive cycle referred to as the "Niobrara Cyclothem" by Kauffman (1977), and ranges in age from latest Turonian to early Campanian. The uppermost Cody, of middle Campanian age, was deposited during a subsequent transgressive-regressive cycle that Kauffman (1977) referred to as the Claggett cycle (fig. 8). The lower and upper contacts of the Cody Shale are conformable and interfinger extensively with the underlying Frontier and overlying Mesaverde Formations (fig. 6).

The Cody Shale is about 3,500 feet (ft) thick in the northwestern part of the basin increasing to more than $5,500 \mathrm{ft}$ in the eastern part (fig. 9). The eastward thickening is due to the eastward stratigraphic rise and intertonguing of the contact between the Cody Shale and the overlying Mesaverde Formation, and the west to northwest backstepping nature of the Frontier/Cody contact (fig. 6). Four members are generally recognized, in ascending order: (1) the lower shaly member (Thompson and White, 1954; Yenne and Pipiringos, 1954; Keefer and Troyer, 1964), (2) the upper sandy member (Thompson and White, 1954; Yenne and Pipiringos, 1954; Keefer and Troyer, 1964), (3) the informally named "Conant Creek tongue" (Szmajter, 1993), and (4) the Wallace Creek Tongue (Barwin, 1961) (figs. 6 and 8). The age of the Cody ranges from latest Turonian to middle Campanian (Keefer, 1972).

The unnamed lower shaly member, which is in part equivalent to the Niobrara Formation (or Member) in the Powder River Basin to the east (figs. 6, 8, and map sheet), reaches a maximum thickness greater than $3,500 \mathrm{ft}$ in the southeastern part of the basin and thins to the northwest to about $1,100 \mathrm{ft}$ (fig. 10). It is composed of gray to black shale, calcareous shale, marl, and bentonite, with minor amounts of siltstone and sandstone that were deposited in an offshore marine environment. The lower shaly member ranges in age from latest Turonian to middle Campanian. 


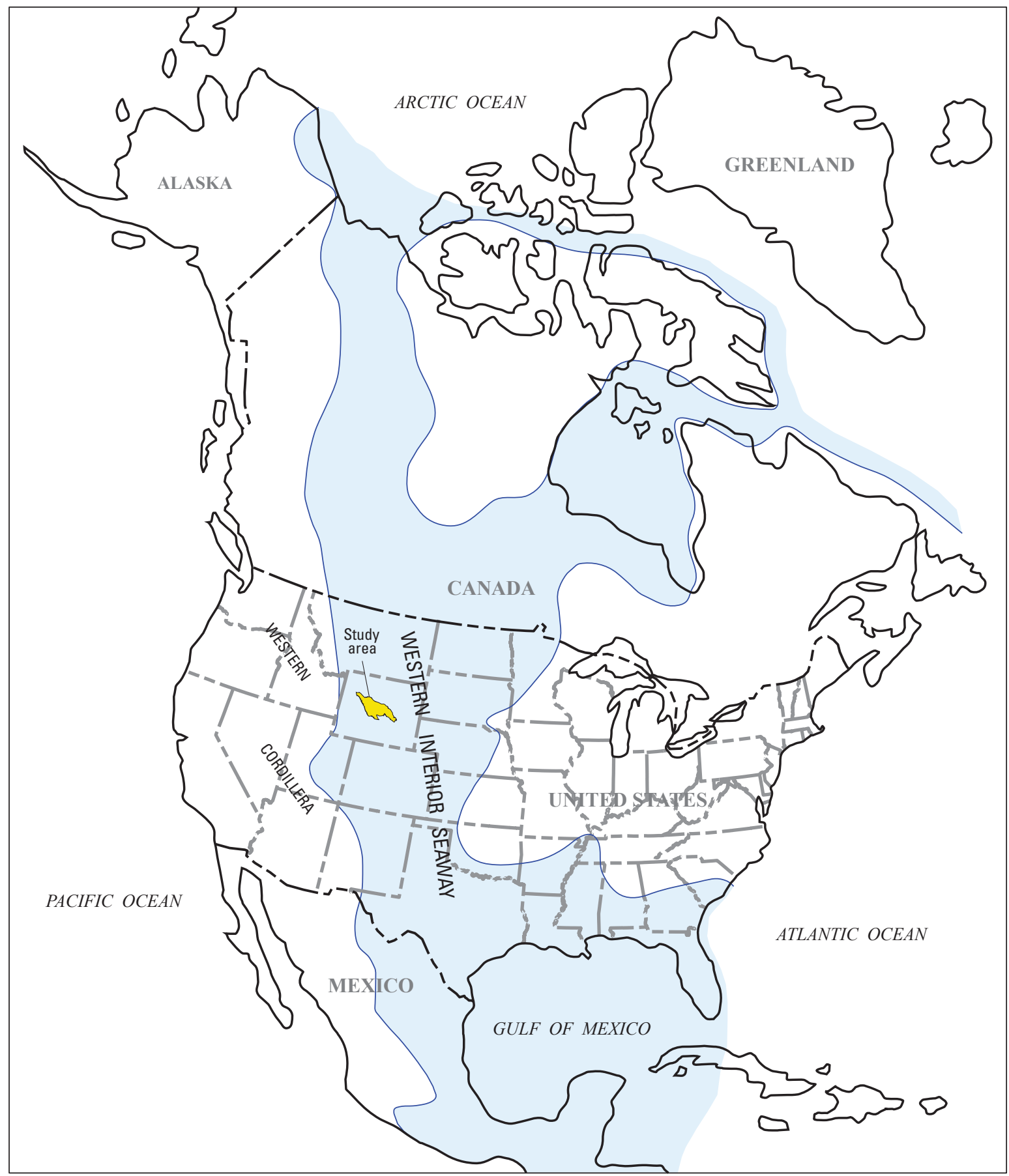

Figure 5. Map showing approximate extent of the Western Interior Seaway in North America during late Coniacian (Scaphites depressus Zone). Modified from Cobban and others (2005).

The upper sandy member is generally around $2,000 \mathrm{ft}$ thick in the western part of the basin and increases to greater than $3,500 \mathrm{ft}$ in the south-central and east-central parts of the basin (fig. 11). It thins to less than $1,000 \mathrm{ft}$ in the southeastern part of the basin where it grades into the lower shaly member (figs. 6, 11, and map sheet). The upper sandy member consists of light to medium gray sandstones and tan and gray shales. Dunleavy and Gilbertson (1986) referred to sandstones in the upper part of the member in the northern part of the basin as the "Sussex" and "Shannon" sandstone beds, which, according to them (p. 115) were deposited "as a near-shore bar complex along the edge of a delta." Like sandstones in the underlying Frontier Formation, many individual sandstones in the upper part of the Cody are continuous for tens of miles before pinching out into marine shale. The upper sandy member becomes less distinct in the southeastern part of the basin, where it grades laterally into more shaly facies (fig. 6, and map sheet) (Finn, 2007b). 


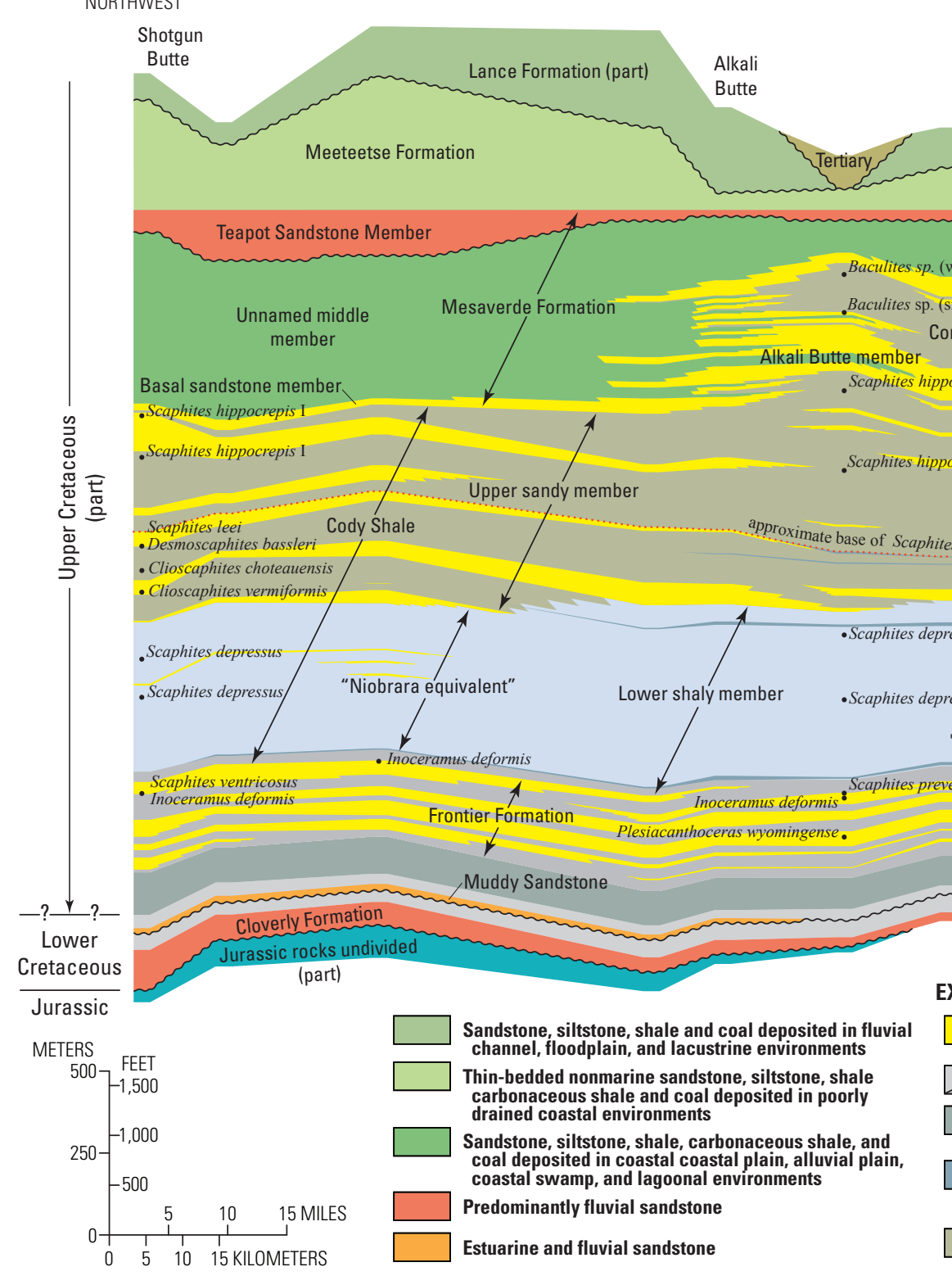

EXPLANATION

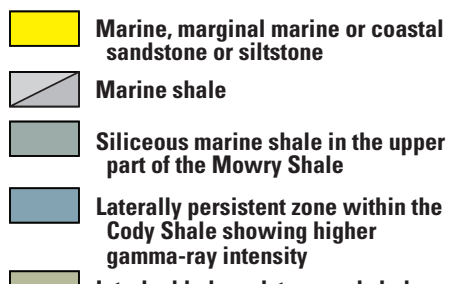
gamma-ray intensity

Interbedded sandstone and shale,

Figure 6. Regional east-west stratigraphic cross section of Cretaceous rocks in the Wind River Basin. Modified from Finn (2007b).

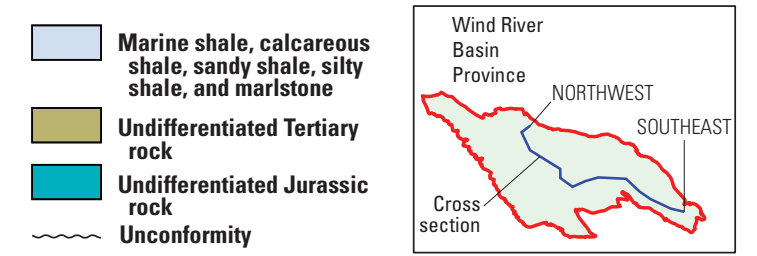

Baculites
eliasi
$\bullet$ important guide fossil

Lewis Shale, upper tongue 


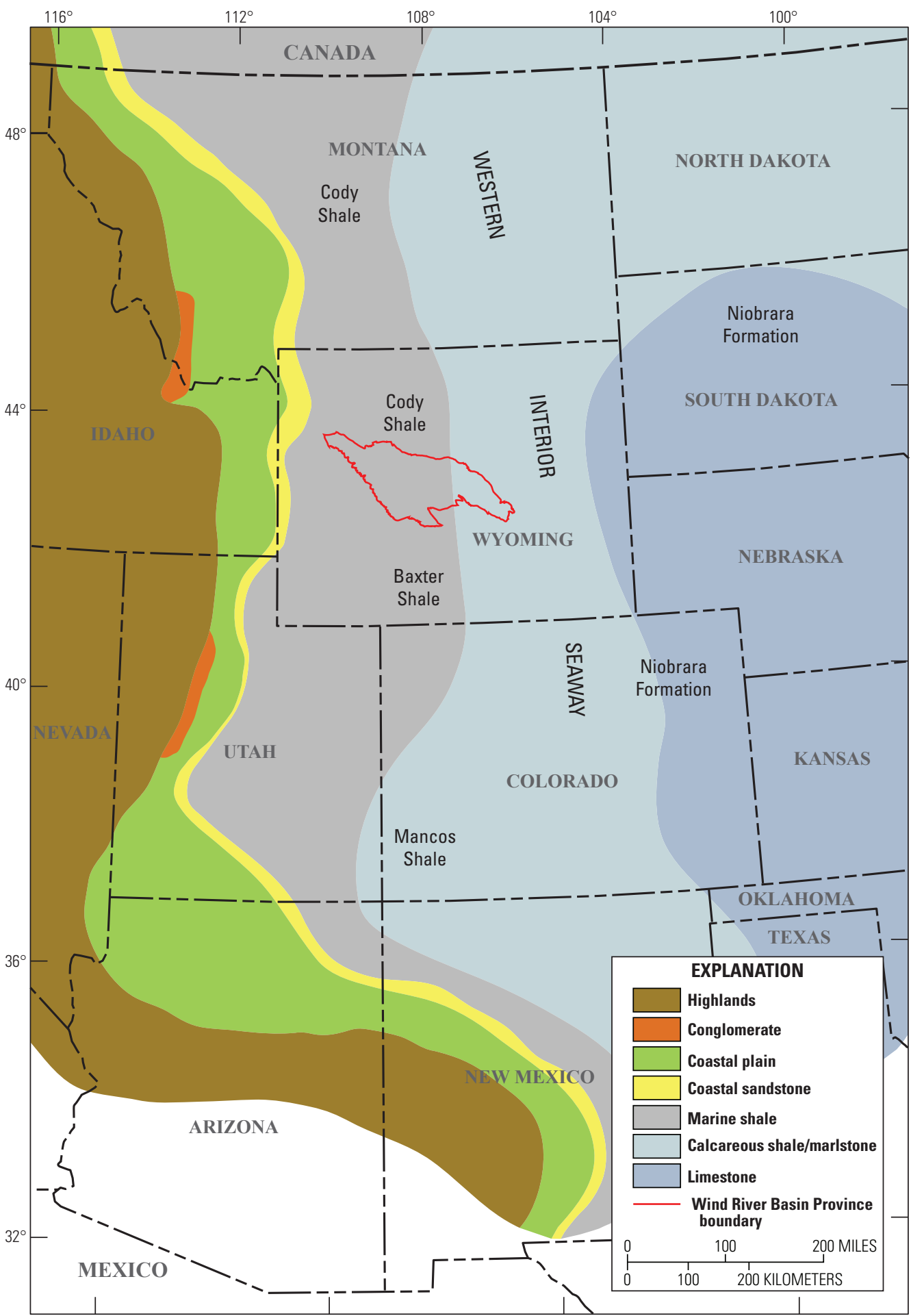

Base from Bureau of Land Management digital data, 2016 Lambert Conformal Conic projection

Standard parallels $33^{\circ}$ and $45^{\circ}$, Central meridian $-108^{\circ}$

Latitude of origin $39^{\circ}$

North American Datum of 1983 (NAD83)

Figure 7. Paleogeographic reconstruction of the Rocky Mountain region during late Coniacian (Scaphites depressus Zone) time showing major depositional trends. Wind River Basin Province outlined in red. Modified from McGookey and others (1972). 


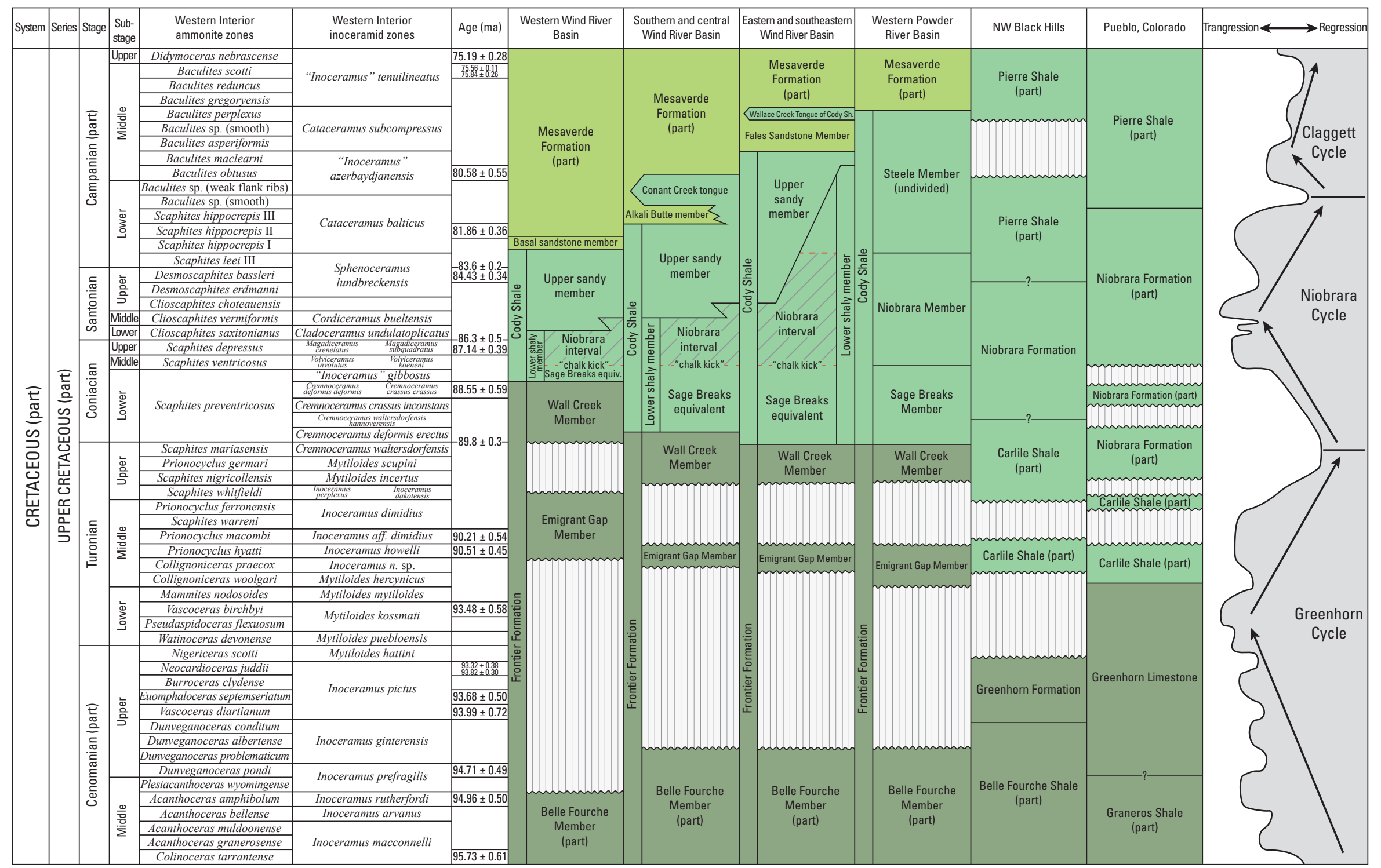

Figure 8. Correlation chart showing stratigraphic relations of mid-Cretaceous rocks in the Wind River Basin and correlation with equivalent rocks at various localities in the Powder River Basin and Denver Basin. The diagonal lines represent the Niobrara interval in the Wind River Basin, as defined in this report. Modified from Keefer (1972), Merewether (1996), Finn (2007b), Merewether and others (2011). Radiometric ages and fossil zones are from Cobban and others (2006), and Merewether and McKinney (2015). Sea-level curve is modified from Kauffman and Caldwell (1993). 


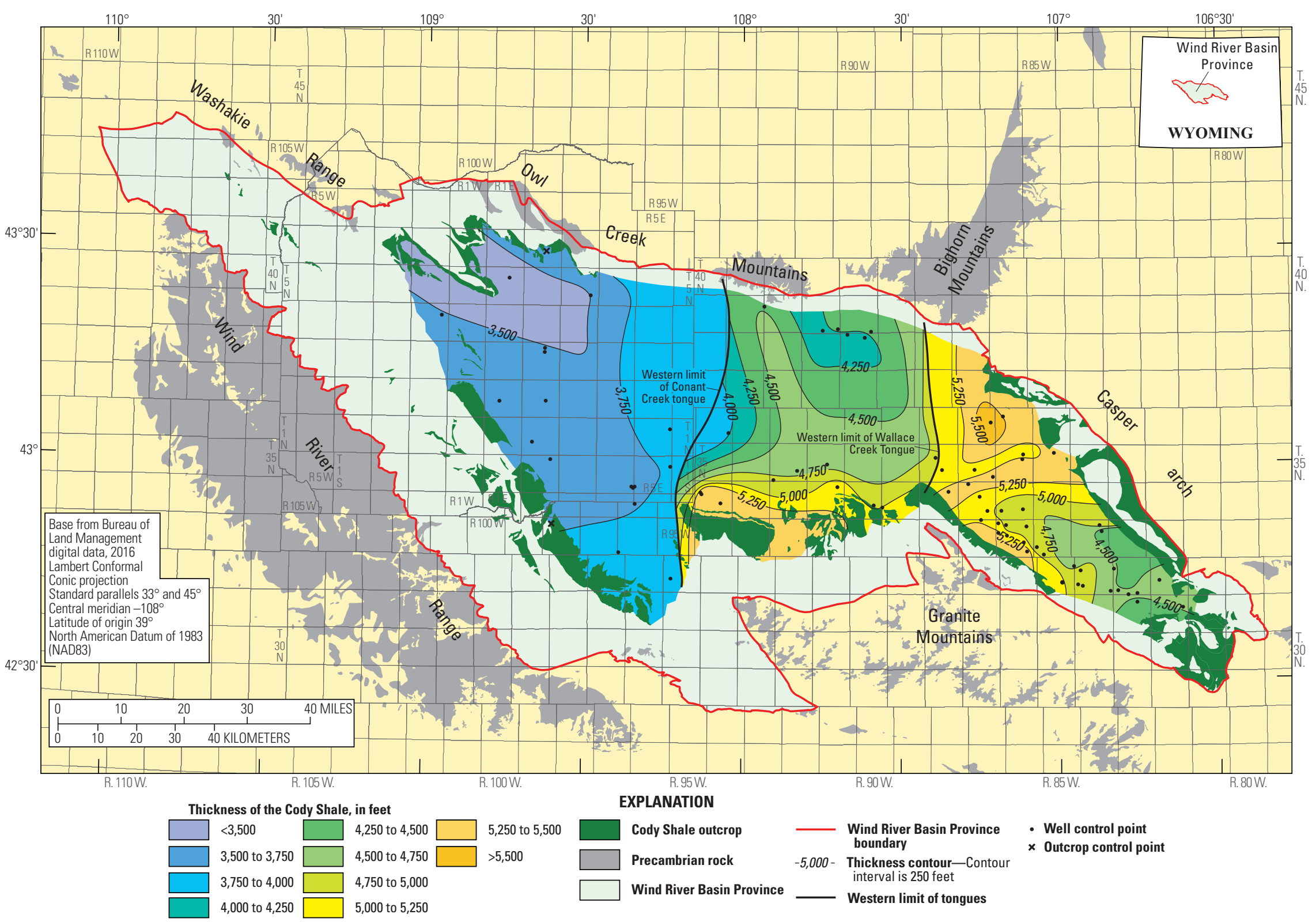

Figure 9. Isopach map of the Cody Shale. This map includes the interval from the top of the uppermost sandstone in the underlying Frontier Formation to the base of the Mesaverde Formation. In the central part of the basin, the interval includes the Alkali Butte member of the Mesaverde Formation and Conant Creek tongue of the Cody Shale. In the eastern part of the basin, the interval includes the Fales Sandstone Member of the Mesaverde and the Wallace Creek Tongue of the Cody. Thickness interval 250 feet. 


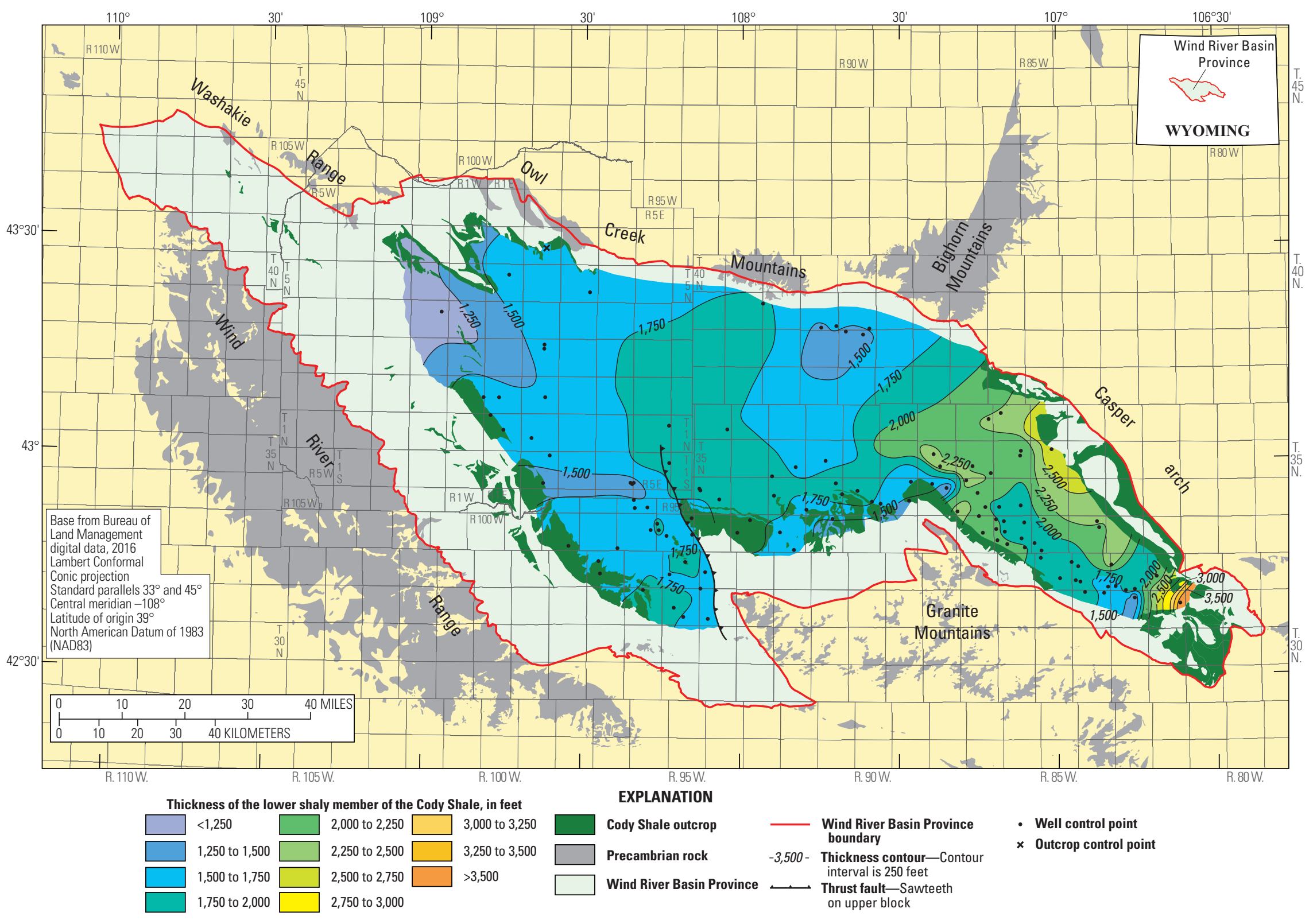

Figure 10. Isopach map of the lower shaly member of the Cody Shale. This map includes the interval from the top of the uppermost sandstone in the underlying Frontier Formation to the base of the upper sandy member of the Cody Shale. Thickness interval 250 feet. 


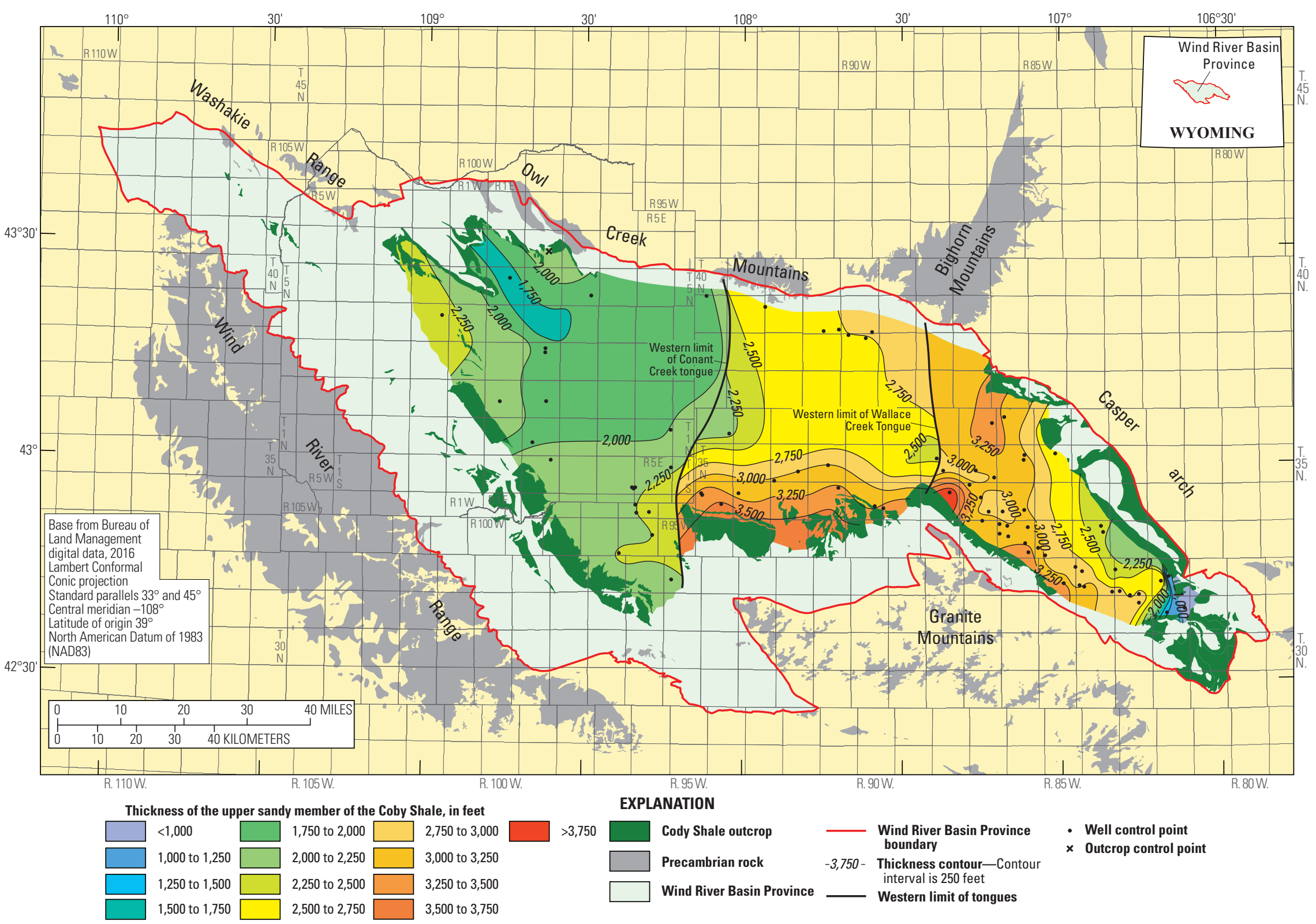

Figure 11. Isopach map of the upper sandy member of the Cody Shale. This map includes the interval from the base of the sandy member to the base of the Mesaverde Formation. In the central part of the basin, the interval includes the Alkali Butte member of the Mesaverde Formation and Conant Creek tongue of the Cody Shale. In the eastern part of the basin, the interval includes the Fales Sandstone Member of the Mesaverde and the Wallace Creek Tongue of the Cody. Thickness interval 250 feet. 
The Conant Creek tongue of the Cody Shale, informally named by Szmajter (1993), trends north-south across the central part of the basin. It is separated from the upper sandy member by an eastward-thinning clastic wedge of marginal marine and nonmarine rocks, informally referred to as the Alkali Butte member of the Mesaverde Formation by Hogle and Jones (1991) (figs. 6 and 8). The Conant Creek tongue is generally 400 to $1,000 \mathrm{ft}$ thick, but thins to zero where it grades westward into nonmarine rocks of the Mesaverde Formation (fig. 6).

The Wallace Creek Tongue of the Cody Shale occupies the eastern and southeastern parts of the Wind River Basin and is stratigraphically higher and younger than the Conant Creek tongue to the west. This member is a westward-thinning tongue of marine shale that separates the Fales Sandstone Member at the base of the Mesaverde Formation from the upper part of the formation (Barwin, 1961) (fig. 6). The Wallace Creek Tongue is nearly $500 \mathrm{ft}$ thick in the southeastern part of the basin and thins to zero in the northern part of the Coalbank Hills, where it grades into the main part of the Mesaverde Formation, (fig. 6).

\section{Niobrara Interval}

The Niobrara equivalent strata in the Wind River Basin are represented by gray to black shale, calcareous shale, marl, and bentonite, with minor amounts of siltstone and sandstone. In many samples, the more calcareous zones are often characterized by varying amounts of coccolith-rich fecal pellets that appear as distinctive "white specks" similar to those described by Hattin (1975). A persistent zone or high-resistivity peak identified on resistivity logs in the lower 50-300 ft of the lower shaly member (fig. 4 and map sheet), referred to as the "chalk kick" marker by Keefer (1972) represents the base of the Niobrara equivalent in the Wind River Basin based on correlations along the Casper arch and into the western Powder River Basin (Merewether and others, 1977a, b; Dunleavy and Gilbertson, 1986; Fox, 1993). The "chalk kick" marker can be traced in the subsurface throughout most of the basin, and based on American Stratigraphic Company (AMSTRAT) sample descriptions from well cuttings it separates noncalcareous shales in the lowermost part of the shaly member from overlying calcareous strata (fig. 4, map sheet). The AMSTRAT sample descriptions from wells in the eastern and southeastern part of the basin indicate that the top of this calcareous interval corresponds to a distinctive gamma ray and electric log response (fig. 4 and map sheet), that has been traced eastward into the top of the Niobrara Member (or Formation) along the Casper arch and into the Powder River Basin by Merewether and others (1977a, b) and Dunleavy and Gilbertson (1986). In the eastern and southeastern parts of the basin, the Niobrara interval ranges from about 750 to $1,500 \mathrm{ft}$ thick (fig. 12). The shaly member above the calcareous Niobrara interval and below the base of the overlying sandy member in this area is composed of shales that are less calcareous to noncalcareous and commonly contain numerous bentonite beds (map sheet). To the west, in the vicinity of Coalbank Hills, and extending along a line roughly north-south between Madden anticline and Tepee Flats to the northern margin of the basin, the upper part of the interval progressively grades into the upper sandy member of the Cody Shale (figs. 6, 12, and map sheet). West of this line only the basal Niobrara strata of the Casper arch and Powder River Basin are represented in the central and western parts of the Wind River Basin (figs. 6, 8, and map sheet). In the central and western parts of the basin, the Niobrara interval ranges from less than 1,000 ft to about $1,800 \mathrm{ft}$ thick (fig. 12).

There is little fossil data available for the Niobrara interval in the eastern and southeastern parts of the basin, however, according to Merewether (1996), W.A. Cobban of the USGS collected and identified several species of marine mollusks from overlying and underlying beds in the western and southwestern parts of the Powder River Basin. These fauna indicate that the Niobrara along the Casper arch and possibly the eastern part of the Wind River Basin are likely middle Coniacian to early Campanian in age (fig. 8). Fossil data reported by Cobban (1951), Yenne and Pipiringos (1954), Keefer and Troyer (1964), Keefer (1972), Landman and Cobban (2007), and files at the USGS fossil collection in Denver, Colorado (K.C. McKinney, USGS, written commun., 2015) for surface sections near Shotgun Butte, Lander, and Conant Creek indicate that the Niobrara interval below the contact with the upper sandy member is middle Coniacian to late Santonian in age in the central and western parts of the basin (fig. 8).

\section{Sage Breaks Interval}

Merewether and others (1977a, b), and Dunleavy and Gilbertson (1986) correlated the interval of the shaly member of the Cody Shale below the "chalk kick" marker and the top of the uppermost sandstone in the Frontier Formation with the Sage Breaks Member of the Cody Shale in the western part of the Powder River Basin (figs. 4 and 8). This interval of noncalcareous marine shale ranges in thickness from about $300 \mathrm{ft}$ in the southeastern part of the basin thinning to less than $50 \mathrm{ft}$ in the western part, reflecting the backstepping pattern of sandstones in the underlying Frontier Formation (figs. 6, 13, and map sheet). Ammonite and inoceramid fossils collected from the underlying Frontier Formation and within the Sage Breaks interval indicate that it is latest Turonian to middle Coniacian in age in the eastern part of the basin, and early to middle Coniacian in age in the central western parts (fig. 8).

\section{Acknowledgments}

This report benefited from reviews by Ron Johnson, Michael Brownfield, and Dave Ferderer of the U.S. Geological Survey (USGS), and their suggestions and comments are greatly appreciated. Important information about fossil collections and locations were provided by K.C. McKinney, curator of the USGS fossil collection in Denver, Colo. 


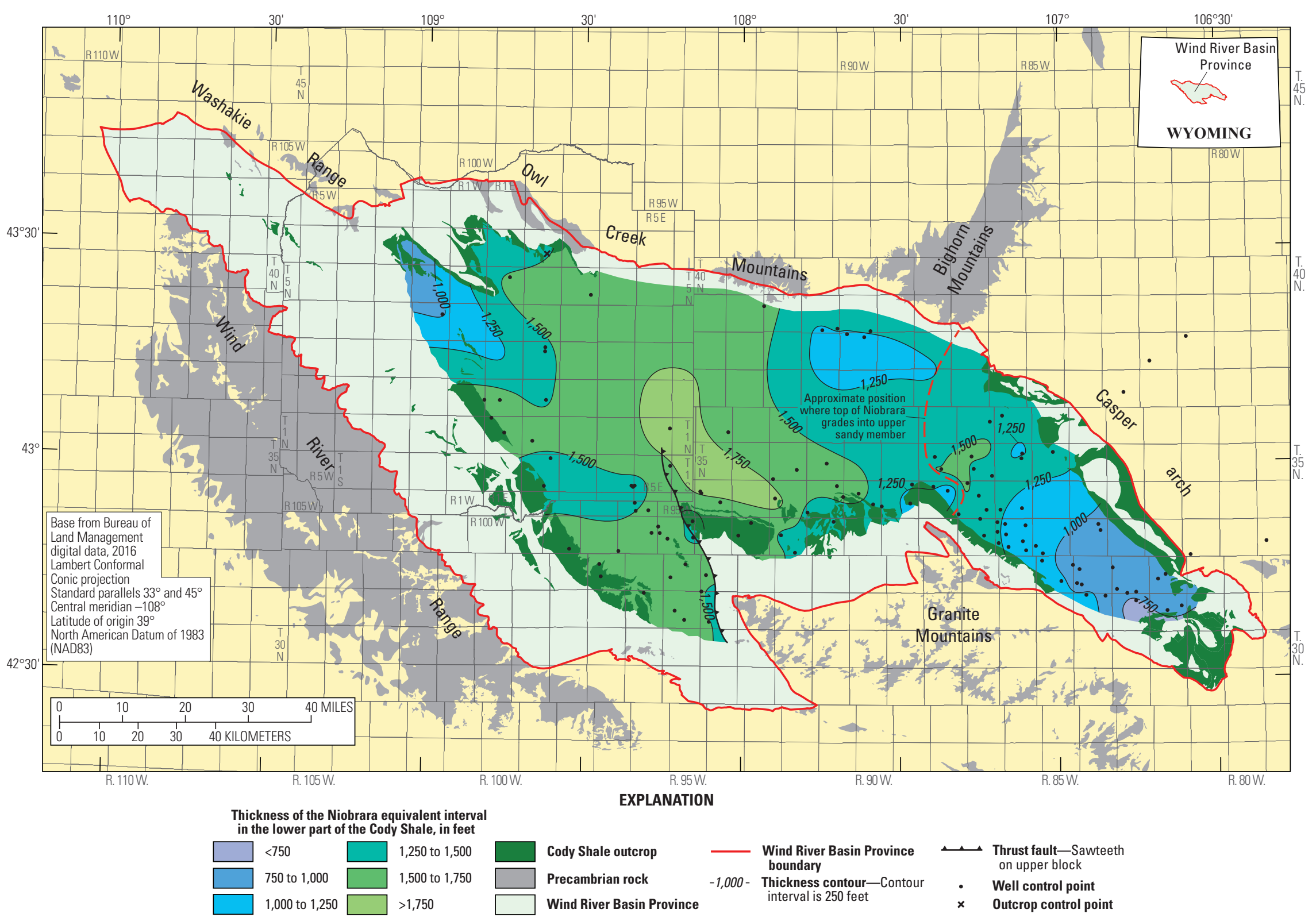

Figure 12. Isopach map of the Niobrara equivalent interval in the lower part of the Cody Shale. In the eastern part of the basin, the map includes the interval from the base of the "chalk kick" marker to the top of the calcareous zone within the lower shaly member of the Cody Shale. In the central and western parts of the basin, the top of the interval is the base of the sandy member of the Cody Shale. Thickness interval 250 feet. 


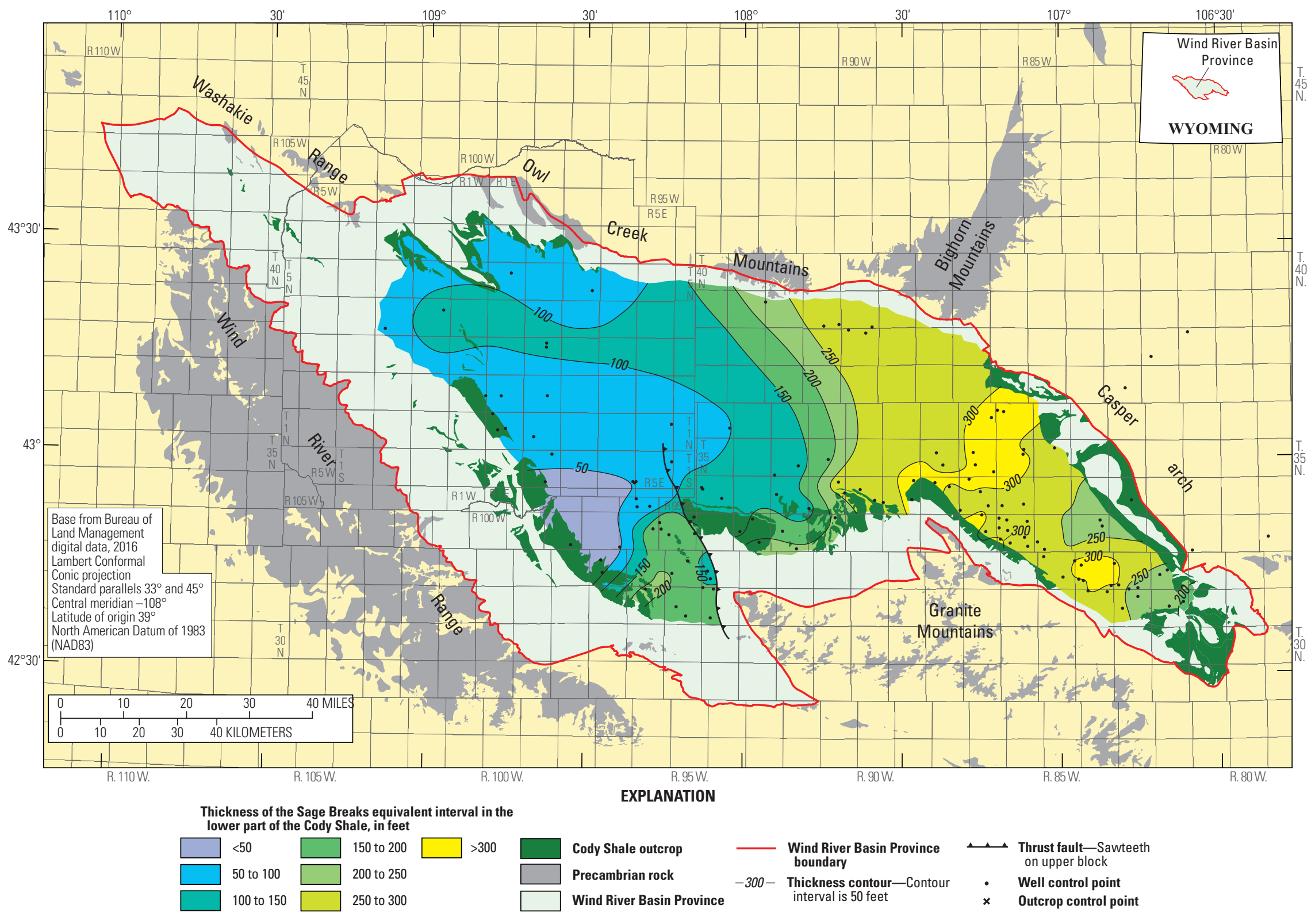

Figure 13. Isopach map of the Sage Breaks equivalent interval in the lower part of the Cody Shale. This map includes the interval from the base of the "chalk kick" marker to the top of the uppermost sandstone in the underlying Frontier Formation. Thickness interval 50 feet. 


\section{References Cited}

Barwin, J.R., 1961, Stratigraphy of the Mesaverde Formation in the southeastern part of the Wind River Basin, Fremont and Natrona Counties, Wyoming: unpublished M.A. thesis, University of Wyoming, $78 \mathrm{p}$.

Biggs, Paul, and Espach, R.H., 1960, Dallas Dome, in Petroleum and natural gas fields in Wyoming: U.S. Bureau of Mines Bulletin 582, p. 83-84.

Cobban, W.A., 1951, Scaphoid cephalopods of the Colorado group: U.S. Geological Survey Professional Paper 239, 42 p. [Also available at https://pubs.er.usgs.gov/publication/pp239.]

Cobban, W.A., 1969, The Late Cretaceous ammonites Scaphites leei Reeside and Scaphites hippocrepis (DeKay) in the Western Interior of the United States: U.S. Geological Survey Professional Paper 619, 29 p. [Also available at https://pubs.er.usgs.gov/publication/pp619.]

Cobban, W.A., Dyman, T.S., and Porter, K.W., 2005, Paleontology and stratigraphy of upper Coniacian-Middle Santonian ammonite zones and application to erosion surfaces and marine transgressive strata in Montana and Alberta: Cretaceous Research, v. 26, p. 429-449.

Cobban, W.A., Walaszczyk, Ireneusz, Obradovich, J.D., and McKinney, K.C., 2006, A USGS zonal table for the Upper Cretaceous middle Cenomanian-Maastrichtian of the Western Interior of the United States based on ammonites, inoceramids, and radiometric ages: U.S. Geological Survey Open-File Report 2006-1250, 45 p. [Also available at https://pubs.er.usgs.gov/publication/ofr20061250.]

Colorado Geological Survey, 2011, Colorado's new oil boom-the Niobrara: Colorado Geological Survey Rock Talk, v. 13, no. 1, 11 p. [Also available at http://coloradogeologicalsurvey.org/publications/rocktalk/.]

De Bruin, R.H., 1993, Overview of oil and gas geology of Wyoming, in Snoke, A.W., Steidtmann, J.R., and Roberts, S.M., eds., Geology of Wyoming: Geological Survey of Wyoming Memoir no. 5, p. 836-873.

Dickinson, W.R., Klute, M.A., Hayes, M.J., Janecke, S.U., Lundin, E.R., McKittrick, M.A., and Olivares, M.D., 1988, Paleographic and paleotectonic setting of Laramide sedimentary basins in the central Rocky Mountain region: Geological Society of America Bulletin, v. 100, p. 1023-1039.

Dunleavy, J.M., and Gilbertson, R.L., 1986, Madden anticline - Growing giant, in Noll, J.H., and Doyle, K.M., eds., Rocky Mountain oil and gas fields: Wyoming Geological Association, p. 107-157.
Finn, T.M., 2007a, Source rock potential of Upper Cretaceous marine shales in the Wind River Basin, Wyoming, chap. 8, of U.S. Geological Survey Wind River Basin Assessment Team, eds., Petroleum systems and geologic assessment of oil and gas resources in the Wind River Basin Province, Wyoming: U.S. Geological Survey Digital Data Series DDS 69-J-8, 24 p., CD-ROM. [Also available at https://pubs. er.usgs.gov/publication/ds69J8.]

Finn, T.M., 2007b, Subsurface stratigraphic cross sections of Cretaceous and Lower Tertiary rocks in the Wind River Basin, central Wyoming, Wyoming, chap. 9 of U.S. Geological Survey Wind River Basin Assessment Team, eds., Petroleum systems and geologic assessment of oil and gas resources in the Wind River Basin Province, Wyoming: U.S. Geological Survey Digital Data Series DDS 69-J-9, 28 p., CD-ROM. [Also available at https://pubs.er.usgs.gov/ publication/ds69J9.]

Fox, J.E., 1993, Stratigraphic cross sections $M-M^{\prime}$ through $R-R$, showing electric logs of Upper Cretaceous and older rocks, Powder River Basin, Wyoming: U.S. Geological Survey Oil and Gas Investigations Chart OC-137. [Also available at https://pubs.er.usgs.gov/publication/oc137.]

Fox, J.E., and Dolton, G.L., 1989, Petroleum geology of the Wind River and Bighorn Basins, Wyoming and Montana: U.S. Geological Survey Open-File Report 87-450-P, 41 p. [Also available at https://pubs.er.usgs.gov/publication/ ofr87450P.]

Fox, J.E., and Dolton, G.L., 1996, Wind River Basin Province (35), in Gautier, D.L., Dolton, G.L., Takahashi, K.I., and Varnes, K.L., eds., 1995 National assessment of United States oil and gas resources-Results, methodology, and supporting data: U.S. Geological Survey Digital Data Series DDS-30, release 2 .

Gries, R.R., Dolson, J.C., and Raynolds, R.G.H., 1992, Structural and stratigraphic evolution and hydrocarbon distribution, Rocky Mountain Foreland, in Macqueen, R.W., and Leckie, D.A., eds., Foreland basins and fold belts: American Association of Petroleum Geologists Memoir 55, p. 395-425.

Hattin, D.E., 1975, Petrology and origin of fecal pellets in Upper Cretaceous strata of Kansas and Saskatchewan: Journal of Sedimentary Petrology, v. 45, no. 3, p. 686-696.

Hogle, D.G., and Jones, R.W., 1991, Subsurface geology of Upper Cretaceous and Lower Tertiary coal-bearing rocks, Wind River Basin, Wyoming: The Mountain Geologist, v. 28 , nos. 2 and 3, p. 13-36.

Jiao, Z.S., and Surdam, R.C., 1997, Characteristics of anomalously pressured Cretaceous shales in the Laramide Basins of Wyoming, in Surdam, R.C., ed., Seals, traps, and the petroleum system: American Association of Petroleum Geologists Memoir 67, p. 243-253. 
Johnson, R.C., and Rice, D.D., 1993, Variations in composition and origins of gases from coal bed and conventional reservoirs, Wind River Basin, Wyoming, in Keefer, W.R., Metzger, W.J., and Godwin, L.H,. eds., Oil and gas and other resources of the Wind River Basin, Wyoming: Wyoming Geological Association, p. 319-335.

Johnson, R.C., Finn, T.M., Crovelli, R.A., and Balay, R.H., 1996, An assessment of in-place gas resources in low-permeability Upper Cretaceous and Lower Tertiary sandstone reservoirs, Wind River Basin, Wyoming: U.S. Geological Survey Open-File Report 96-264, 67 p. [Also available at https://pubs.er.usgs.gov/publication/ofr96264.]

Johnson, R.C., Finn, T.M., Kirschbaum, M.A., Roberts, S.B., Roberts, L.N.R., Cook, T., and Taylor, D.J., 2007, The Cretaceous-Lower Tertiary Composite Total Petroleum System, Wind River Basin, Wyoming, chap. 4, of Petroleum Systems and Geologic Assessment of Oil and Gas Resources in the Wind River Basin Province, Wyoming: U.S. Geological Survey Digital Data Series DDS 69-J-4, 96 p., CD-ROM.

Kauffman, E.G., 1977, Geological and biological overview Western Interior Cretaceous basin, in Kauffman, E.G., ed., Cretaceous facies, faunas, and paleoenvironments across the Western Interior Basin: The Mountain Geologist, v. 14, nos. 3 and 4, p. 75-99.

Kauffman, E.G., and Caldwell, W.G.E., 1993, The Western Interior Basin in space and time, in Caldwell, W.G.E., and Kauffman, E.G., eds., Evolution of the Western Interior Basin: Geological Association of Canada, Special Paper 39, p. 1-30.

Keefer, W.R., 1969, Geology of petroleum in the Wind River Basin, central Wyoming: American Association of Petroleum Geologists Bulletin, v. 53, no. 9, p. 1839-1865.

Keefer, W.R., 1972, Frontier, Cody, and Mesaverde Formations in the Wind River and southern Bighorn Basins, Wyoming: U.S. Geological Survey Professional Paper 495-E, 23 p. [Also available at https://pubs.er.usgs.gov/publication/pp495E.]

Keefer, W.R., 1997, Stratigraphy and correlation of Cretaceous and Paleocene rocks, northern Wind River Basin, Wyoming, U.S. Geological Survey Oil and Gas Investigations Chart OC.146-A. [Also available at https://pubs.er.usgs.gov/publication/oc146A.]

Keefer, W.R., and Troyer, M.L., 1964, Geology of the Shotgun Butte area, Fremont County, Wyoming: U.S. Geological Survey Bulletin 1157, 123 p. [Also available at https://pubs. er.usgs.gov/publication/b1157.]

Keefer, W.R., and Johnson, R.C., 1993, Stratigraphy and oil and gas resources in uppermost Cretaceous and Paleocene rocks, Wind River Basin, Wyoming, in Keefer, W.R., Metzger, W.J., and Godwin, L.H., eds., Oil and gas and other resources of the Wind River Basin: Wyoming Geological Association Special Symposium, p. 71-85.
Landman, N.N., and Cobban, W.A., 2007, Redescription of the Late Cretaceous (late Santonian) ammonite Desmoscaphites bassleri Reeside, 1927, from the Western Interior of North America: Rocky Mountain Geology, v. 42, no. 2, p. 67-94.

Longman, M.W., Luneau, B.A., and Landon, S.M., 1998, Nature and distribution of Niobrara lithologies in the Cretaceous Western Interior Seaway of the Rocky Mountain Region: The Mountain Geologist, v. 35, no. 4, p. 137-170.

McGookey, D.P., Haun, J.D., Hale, L.A., Goodale, H.G., McCubbin, D.G., Weimer, R.J., and Wulf, G.R., 1972, Cretaceous System, in Mallory, W.W., Mudge, M.R., Swanson, V.E., Stone, D.S., and Lumb, W.E., eds., Geologic atlas of the Rocky Mountain Region: Rocky Mountain Association of Geologists, p. 190-228.

Meissner, F.F., Woodward, Jane., and Clayton, J.L., 1984, Stratigraphic relationships and distribution of source rocks in the greater Rocky Mountain region, in Woodward, Jane., Meissner, F.F., and Clayton, J.L., eds., Hydrocarbon source rocks of the greater Rocky Mountain region: Rocky Mountain Association of Geologists Guidebook, p. 1-34.

Merewether, E.A., 1996, Stratigraphy and tectonic implications of Upper Cretaceous rocks in the Powder River Basin, northeastern Wyoming and southeastern Montana: U.S. Geological Survey Bulletin 1917-T, 92 p. [Also available at https://pubs.er.usgs.gov/publication/b1917T.]

Merewether, E.A., Cobban, W.A., Matson, R.M., and Magathan, W.J., 1977a, Stratigraphic diagrams with electric logs of Upper Cretaceous rocks, Powder River Basin, Natrona, Converse, and Weston Counties, Wyoming, section $B-B^{\prime}$ : U.S. Geological Survey Oil and Gas Investigations Map OC-74. [Also available at https://pubs.er.usgs.gov/publication/oc74.]

Merewether, E.A., Cobban, W.A., Matson, R.M., and Magathan, W.J., 1977b, Stratigraphic diagrams with electric logs of Upper Cretaceous rocks, Powder River basin, Natrona, Converse, and Niobrara Counties, Wyoming, section $C-C^{\prime}$ : U.S. Geological Survey Oil and Gas Investigations Map OC-75. [Also available at https://pubs.er.usgs.gov/publication/oc75.]

Merewether, E.A., and Cobban, W.A., 2007, Outcrop descriptions and fossils from the Upper Cretaceous Frontier Formation, Wind River Basin and adjacent areas, Wyoming chap. 11 of U.S. Geological Survey Wind River Basin Assessment Team, eds., Petroleum systems and geologic assessment of oil and gas resources in the Wind River Basin Province, Wyoming: U.S. Geological Survey Digital Data Series DDS 69-J-11, 95 p., CD-ROM. [Also available at https://pubs. er.usgs.gov/publication/ds69J11.] 
Merewether, E.A., Cobban, W.A., and Obradovich, J.D., 2011, Biostratigraphic data from Upper Cretaceous FormationEastern Wyoming, central Colorado, and northeastern New Mexico: U.S. Geological Survey Scientific Investigations Map 3175, 10 p., 2 sheets. [Also available at https://pubs. er.usgs.gov/publication/sim3175.]

Merewether, E.A., and McKinney, K.C., 2015, Chronostratigraphic cross section of Cretaceous formations in western Montana, western Wyoming, eastern Utah, northeastern Arizona, and northwestern New Mexico, U.S.A.: U.S. Geological Survey Open-File Report 2015-1087, 10 p., 1 sheet, http://dx.doi.org/10.3133/ofr20151087.

Molenaar, C.M., and Rice, D.D., 1988, Cretaceous rocks of the Western Interior Basin, in Sloss, L.L., ed., Sedimentary cover-North American craton, U.S.: Geological Society of America, The Geology of North America, v. D-2, p. 77-82.

Nuccio, V.F., Finn, T.M., and Johnson, R.C., 1996, Thermal maturity data for the assessment of gas resources in the Wind River Basin, Wyoming: U.S. Geological Survey Open-File Report 96-064, 57 p. [Also available at https:// pubs.er.usgs.gov/publication/ofr9664.]

Schelling, D.D., and Wavrek, D.A., 1999, Structural geology and petroleum systems of the Madden field, Wind River Basin, Wyoming: American Association of Petroleum Geologists, v. 83, no. 13 (supplement).

Schelling, D.D., and Wavrek, D.A., 2001, Structural geology and petroleum systems of the northwestern Wind River Basin, Wyoming: American Association of Petroleum Geologists, v. 85, no. 13 (supplement).

Sonnenberg, S.A., 2011, The Niobrara Petroleum SystemA new resource play in the Rocky Mountain Region, in Estes-Jackson, J.E., and Anderson, D.S., eds., Revisiting and revitalizing the Niobrara in the central Rockies: Rocky Mountain Association of Geologists, p. 13-32.

Spencer, C.W., 1987, Hydrocarbon generation as a mechanism for overpressuring in Rocky Mountain region: American Association of Petroleum Geologists Bulletin, v. 71, no. 4, p. $368-388$.

Steidtmann, J.R., 1993, The Cretaceous foreland basin and its sedimentary record, in Snoke, A.W., Steidtmann, J.R., and Roberts, S.M., eds., Geology of Wyoming: Geological Survey of Wyoming Memoir no. 5, p. 250-271.

Surdam, R.C., Jiao, Z.S., and Heasler, H.P., 1997, Anomalously pressured gas compartments in Cretaceous rocks of the Laramide basins of Wyoming-A new class of hydrocarbon accumulation, in Surdam, R.C., ed., Seals, traps, and the petroleum system: American Association of Petroleum Geologists Memoir 67, p. 199-222.
Szmajter, R.J., 1993, Subsurface stratigraphic cross section of Lower and Upper Cretaceous rocks in the south-central Wind River Basin, Wyoming, in Keefer, W.R., Metzger, W.J., and Godwin, L.H,. eds., Oil and gas and other resources of the Wind River Basin, Wyoming: Wyoming Geological Association, p. 87-90.

Thompson, R.M., and White, V.L., 1954, Geology of the Riverton area, central Wyoming: U.S. Geological Survey Oil and Gas Investigations Map OM-127

Williams, Peggy, and Lyle, Don, 2011, Bring in the rigs, in Estes-Jackson, J.E., and Anderson, D.S., eds., Revisiting and revitalizing the Niobrara in the central Rockies: Rocky Mountain Association of Geologists, p. 33-40.

Yenne, K.A., and Pipiringos, G.N., 1954, The Cody Shale and younger Cretaceous and Paleocene rocks in the Wind River Basin, Fremont County, Wyoming: U.S. Geological Survey Oil and Gas Investigations Chart OC-49. [Also available at https://pubs.er.usgs.gov/publication/oc49.]

Publishing support provided by:

Denver Publishing Service Center

For more information concerning this publication, contact:

Center Director, USGS Central Energy Resources Science Center

Box 25046, Mail Stop 939

Denver, C0 80225

(303) 236-1647

Or visit the Central Energy Resources Science Center Web site at: http://energy.usgs.gov/ 



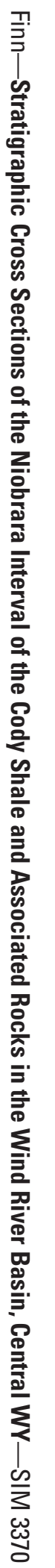

